\title{
Regulation of Eicosanoid Production and Mitogenesis in Rat Intestinal Epithelial Cells by Transforming Growth Factor- $\alpha$ and Phorbol Ester
}

\author{
Raymond N. DuBois, ${ }^{\star \star \|} \|$ Joseph Awad, ${ }^{\star \|}$ Jason Morrow, ${ }^{\star}$ L. Jackson Roberts, II, ${ }^{\star}$ and Phyllis R. Bishop ${ }^{5}$ \\ Departments of ${ }^{*}$ Medicine, ${ }^{\ddagger}$ Cell Biology, and ${ }^{\S}$ Pediatrics, Vanderbilt University Medical Center; and ${ }^{\| V e t e r a n s ~ A f f a i r s ~ M e d i c a l ~ C e n t e r, ~}$ \\ Nashville, Tennessee 37232
}

\begin{abstract}
Growth factors and tumor promoters have been shown to play a role in intestinal epithelial growth regulation and transformation. In this study, transforming growth factor- $\alpha$ (TGF $\alpha)$ and the tumor promoter, tetradecanoyl phorbol acetate (TPA), are shown to stimulate the production of eicosanoids by rat intestinal epithelial (RIE-1) cells in culture. A 4.5-kb mRNA, which hybridizes to the mouse cyclooxygenase- 2 cDNA probe, is elevated 18-fold within $30 \mathrm{~min}$ after TGF $\alpha$ or TPA treatment. Stimulation of RIE-1 cells with TGF $\alpha$ leads to the increase of a protein $\left(M_{\mathrm{r}} \sim 69,000\right)$, which binds a monospecific antibody to the mouse cyclooxygenase- 2 protein. Dexamethasone markedly inhibits the increase of the 4.5-kb mRNA. Pretreatment of TGF $\alpha$ or TPA-stimulated RIE-1 cells with dexamethasone or cyclooxygenase inhibitors prevents the increase in eicosanoid production by these cells. Treatment of quiescent RIE-1 cells with TGF $\alpha$ stimulates mitogenesis. This mitogenic activity is blocked by pretreating the cells with dexamethasone or cyclooxygenase inhibitors. A mitogen-inducible cyclooxygenase gene is thus shown to be regulated by TGF $\alpha$ and TPA in rat intestinal epithelial cells. We suggest that products of an intestinal growth factor-inducible cyclooxygenase may play a role in the regulation of mitogenesis. (J. Clin. Invest. 1994. 93:493-498.) Key words: growth • gene $\bullet$ neoplasia • prostaglandins $\bullet$ intestine
\end{abstract}

\section{Introduction}

Cyclooxygenase $(\mathrm{COX})^{1}$ is a key enzyme in the conversion of arachidonic acid to prostanoids. Recent clinical studies indicate that cyclooxygenase inhibitors may affect intestinal polyp formation and/or the development of colon cancer in humans (1-6). One study convincingly demonstrated that colon polyp size and number decreased dramatically in familial adenomatous polyposis patients treated with sulindac, a pro-drug that is converted to a cyclooxygenase inhibitor in the colon, (5). Fa-

Address correspondence to Dr. Raymond N. DuBois, Department of Medicine/GI, Medical Center North C-2104, Vanderbilt University Medical Center, Nashville, TN 37232.

Received for publication 21 July 1993 and in revised form 1 September 1993.

1. Abbreviations used in this paper: $\mathrm{COX}$, cyclooxygenase; GC/NICIMS, gas chromatography negative ion chemical ionization-mass spectrometry; RIE, rat intestinal epithelial; TPA, 12-O-tetradecanoylphorbol-13-acetate; TX, thromboxane.

J. Clin. Invest.

(c) The American Society for Clinical Investigation, Inc.

$0021-9738 / 94 / 02 / 0493 / 06 \$ 2.00$

Volume 93, February 1994, 493-498 milial adenomatous polyposis is an autosomal dominant disorder in which virtually all of those affected will develop colorectal cancer by the fifth decade of life if untreated (7). In epidemiologic studies, cyclooxygenase inhibitors (like aspirin) have been shown to decrease the relative rate of colon cancer by $\sim 40-50 \%$ in humans (1-4). The mechanism by which cyclooxygenase inhibitors cause either polyp regression or lower the relative rate of colon cancer is unknown. The precise relationship between eicosanoid metabolism, intestinal epithelial growth regulation, and carcinogenesis is presently an area of active investigation (2).

One of the immediate early genes, which has been cloned from stimulated mouse fibroblasts, encodes a protein with remarkable homology to prostaglandin G/H synthase (PGHS; 8,11,14-icosatrienoate-hydrogen-donor/oxygen oxidoreductase, EC 1.14.99.1) or cyclooxygenase. This immediate early gene has been referred to by the following designations: TIS 10 (8), PGHS II (9), COX-2 (10), griPGHS (11), and pghsB (12). "Immediate early" or "early growth response" genes comprise a diverse group of genes whose expression rapidly increases in response to growth stimulation in a number of biological systems (13-16). These genes encode polypeptides with a variety of functions, including nuclear transcription factors, cytoplasmic enzymes, membrane proteins, and cytokines. They are induced within $30 \mathrm{~min}$ after serum or growth factor treatment of quiescent cells in culture, and the increase in their mRNA levels is independent of new protein synthesis. Due to their dramatic induction after growth stimulation, it has been assumed that this group of genes plays a role in the regulation of cell growth. Some of the immediate early transcription factors (c-fos and c-jun) have been shown directly to play an important role in growth regulation (17-19).

In this study, we report the regulation of an intestinal epithelial cyclooxygenase gene by TGF $\alpha$ and TPA. TGF $\alpha$ is a member of the epidermal growth factor family of mitogens and associated with progression of transformed properties in human colon cancer cells (20). Rat intestinal epithelial (RIE-1) cells were derived from intestine, established in culture, and initially characterized by Blay and Brown (21). These cells, which are nontransformed, maintain epithelial cell markers, and are mitogenically responsive to $\operatorname{EGF}(21,22)$ and TGF $\alpha$ (22) in culture. We have recently shown that treatment of these cells with TGF $\alpha$ causes a dramatic induction of several immediate early genes at the transcriptional level (22). Here we demonstrate that the COX-2 enzyme is induced and eicosanoid production increased after TGF $\alpha$ or TPA treatment of RIE-1 cells. Addition of a potent cyclooxygenase inhibitor (sulindac sulfide) or glucocorticoids (dexamethasone) before growth factor treatment inhibits the incorporation of $\left[{ }^{3} \mathrm{H}\right]$ thymidine into DNA during $\mathrm{S}$ phase. This work represents the first report of the presence of the COX-2 pathway in rat intestinal epithelial cells and of agonist-mediated regulation at the level of mRNA expression, protein production, and eicosanoid product forma- 
tion. However, the COX-2 protein is present in cultured tracheal epithelial cells (23). In human clinical studies, cyclooxygenase inhibitors have been shown to decrease polyp number, size, and the incidence of colon cancer. The precise mechanism for these clinical findings remains unknown. The studies reported here demonstrate that this pathway of eicosanoid metabolism (COX-2) needs to be considered in future research designed to evaluate the molecular basis for the development of colonic adenomas in humans.

\section{Methods}

Cell culture, RNA isolation, and Northern blot analysis. RIE-1 cells were a gift from Ken Brown (Cambridge Research Station, Babraham, Cambridge, UK). Cells were grown in DME supplemented with $10 \%$ FBS (Lot No. 11151032; Hyclone Laboratories, Logan, UT), 2 mM L-glutamine, 100,000 U/liter penicillin $\mathrm{G}$, and 100,000 $\mu \mathrm{g}$ / liter streptomycin sulfate. Cells were carried for no more than 10 passages, and for all experiments $70-95 \%$ confluent cultures were rendered quiescent by incubating in serum-free DME for 72 hours before growth stimulation. Messenger RNA was isolated from RIE-1 cells as described (24) using type 3 oligo-d(T) cellulose (Collaborative Research, Inc., Bedford, MA). RNA samples were electrophoresed in denaturing agarose gels and transferred to nitrocellulose. Nitrocellulose blots were hybridized using conditions previously described (25) with ${ }^{32} \mathrm{P}$-labeled cDNAs encoding immediate early genes Zif/ 268 and Nup/475 or with ${ }^{32} \mathrm{P}$-labeled cDNA probes for murine prostaglandin $\mathrm{H}$ synthase- 1 and prostaglandin $\mathrm{H}$ synthase-2 (COX-2; Oxford Biomed Res, Inc.; Oxford, MI). Cyclophilin IB-15 was utilized as a constitutive cDNA probe. Results from autoradiographs after equivalent exposure times were quantified by scanning densitometry and expressed as fold increase after normalization to cyclophilin gene expression.

Preparation and labeling of $c D N A$ probes. Ampicillin ${ }^{\mathrm{R}}$ plasmids (pBluescript; Stratagene Corp., La Jolla, CA; or pGEM-2; Promega Corp., Madison, WI) containing the cDNAs of interest were transformed into competent Escherichia coli and the bacteria were grown in medium containing $150 \mu \mathrm{g} / \mathrm{ml}$ ampicillin overnight. Milligram quantities of the plasmids were prepared according to established methods (QIAGEN Inc., Chatsworth, CA) and the cDNA fragments were excised using the appropriate restriction enzymes and purified using low melt agarose gel electrophoresis and NACS ${ }^{\circledR}$ chromatography (Gibco, BRL; Grand Island, NY). Complementary DNA probes were $\left[\alpha-{ }^{32} \mathrm{P}\right]-$ dCTP labeled using a commercially available nick translation kit (Boehringer Mannheim Biochemicals, Indianapolis, IN) and purified using NICK ${ }^{\circledast}$ column chromatography (Pharmacia LKB, Piscataway, $\mathrm{NJ})$ before use.

Isolation of microsomal fractions and Western blotting. Microsomal fractions were isolated as described (26). Western blotting was carried out as described (27), with the following modifications. Microsomal proteins were resuspended into a $10 \mathrm{mM}$ Tris- $\mathrm{HCl}$ buffer, $\mathrm{pH}$ 7.5 , using a glass Teflon homogenizer (Wheaton, Millville, NJ). Protein concentrations were determined using an assay (BioRad Laboratories, Hercules, CA), equivalent amounts of protein were electrophoresed by discontinuous SDS-PAGE (28), and the proteins were electrophoretically transferred to nitrocellulose filters (Transblot; BioRad Laboratories). After transfer, the filters were incubated in a blocking solution ( $10 \mathrm{mM}$ Tris- $\mathrm{HCl}, 150 \mathrm{mM} \mathrm{NaCl}, 5 \% \mathrm{BSA}, \mathrm{pH} 7.4$ ) for 30 min at $40^{\circ} \mathrm{C}$ and then incubated with a primary rabbit anti-mouse COX-2 antibody (Oxford Biomed Res, Inc.). The filters were washed three times in washing solution $(10 \mathrm{mM}$ Tris- $\mathrm{HCl}, 150 \mathrm{mM} \mathrm{NaCl}$, $0.05 \%$ Tween $20, \mathrm{pH} \mathrm{7.4)} \mathrm{and} \mathrm{incubated} \mathrm{with} \mathrm{the} \mathrm{secondary} \mathrm{goat} \mathrm{anti-}$ rabbit IgG alkaline phosphatase conjugated antibody (Promega Corp). After washing three times as before, the filters were incubated in a solution containing substrate for the alkaline phosphatase enzyme as described (25).

Mitogenic assay. DNA synthesis was measured by $\left[{ }^{3} \mathrm{H}\right]$ thymidine incorporation into TCA precipitable material. Serum-starved RIE-1 cells plated in multi-well dishes were exposed to various growth factors and/or inhibitors in triplicate. The mitogenic activity of serum-starved cells was evaluated by BrdU staining using a commercially available kit purchased from Amersham International, (Arlington Heights, IL). Only $4.3 \%$ of the nuclei in the serum-starved cells stained positive for BrdU, while $40.2 \%$ of the nuclei were positive $18 \mathrm{~h}$ after TGF $\alpha$ treatment. After $18 \mathrm{~h}$ of treatment, $1 \mu \mathrm{Ci}\left[{ }^{3} \mathrm{H}\right]$ thymidine was added to each well for $2 \mathrm{~h}$. TCA-precipitable material was solubilized in $300 \mu \mathrm{l}$ of 0.2 $\mathrm{N} \mathrm{NaOH}$ containing $40 \mu \mathrm{g} / \mathrm{ml}$ salmon sperm DNA and $100 \mu \mathrm{l}$ removed for liquid scintillation counting. $\left[{ }^{3} \mathrm{H}\right]$ Thymidine incorporation was found to increase an average of sevenfold $18 \mathrm{~h}$ after TGF $\alpha$ treatment, with a range of 4.5-10 ( $n=10$ experiments).

Measurement of prostanoid levels. Serum-starved RIE-1 cells were treated with fresh serum-free DME containing TGF $\alpha(10 \mathrm{ng} / \mathrm{ml})$ or TPA ( $100 \mathrm{ng} / \mathrm{ml}$; Sigma Chemical Co., St. Louis, MO) for $4 \mathrm{~h}$. Arachidonic acid (> 99\% pure, Nu Chek Prep. Inc., Elysian, MN) was added for the last $15 \mathrm{~min}$ of the incubation at a final concentration of $20 \mu \mathrm{M}$. Medium was removed from the cells and immediately placed at $-70^{\circ} \mathrm{C}$ until the time of assay. Prostanoids were measured by a stable isotope dilution assay utilizing gas chromatography/negative ion chemical ionization-mass spectrometry (GC/NICI-MS) as described (29).

\section{Results}

Coordinate regulation of Nup 475, Zif 268, and a mitogen-inducible cyclooxygenase $m R N A$ and protein. Previous work in our laboratory has demonstrated that a number of early growth response genes are transcriptionally activated in RIE-1 cells within $30 \mathrm{~min}$ after growth factor or serum treatment (22). The experiments reported here were initiated to determine if eicosanoid production is affected after growth stimulation of RIE-1 cells and if the mRNA encoding the mitogen-inducible cyclooxygenase is regulated by growth factor treatment. The RIE-1 cells were grown to $80 \%$ confluence in the presence of $10 \% \mathrm{FBS}$ and then placed in serum-free medium for $72 \mathrm{~h}$. The cells were then treated with medium containing either $10 \%$ FBS or TGF $\alpha(10 \mathrm{ng} / \mathrm{ml})$ and at the indicated times cells were harvested and poly $(\mathrm{A})^{+} \mathrm{mRNA}$ isolated. Northern blots were prepared and probed with the ${ }^{32} \mathrm{P}$-labeled cDNAs indicated in Fig. 1. The results of this experiment demonstrate that the mRNAs encoding the immediate early genes zif/268 and nup/ 475 are markedly elevated within 30 min after growth factor or serum treatment. A 4.5-kb mRNA, which hybridizes to the murine mitogen-inducible PGH synthase (COX-2) cDNA probe is increased 18 -fold within 30 min after growth stimulation and remains elevated for up to $2 \mathrm{~h}$ after treatment. The cyclophilin 1B-15 mRNA is constitutively expressed and its level does not change with growth factor treatment; therefore, this Northern blot was hybridized with a ${ }^{32}$ P-labeled cyclophilin 1B-15 cDNA to verify that equivalent amounts of RNA were loaded in each lane. When the Northern blot was probed with a ${ }^{32} \mathrm{P}$-labeled COX-1 cDNA probe, we detected very low levels of a 2.8-kb mRNA that did not increase after growth factor or serum treatment (data not shown). This experiment demonstrates that only the mitogen-inducible cyclooxygenase is selectively regulated in growth-stimulated RIE-1 cells.

Since cyclooxygenase is located in the endoplasmic reticulum, microsomal fractions were isolated from quiescent and TGF $\alpha$-stimulated RIE-1 cells, and Western blots of the microsomal proteins were prepared and incubated with a commercially available monospecific polyclonal rabbit anti-mouse COX-2 antibody (Oxford Biomed Res, Inc.). Microsomal fractions isolated from quiescent cells do not contain detectable COX-2 protein; whereas, $6 \mathrm{~h}$ after stimulation by TGF $\alpha$ there 

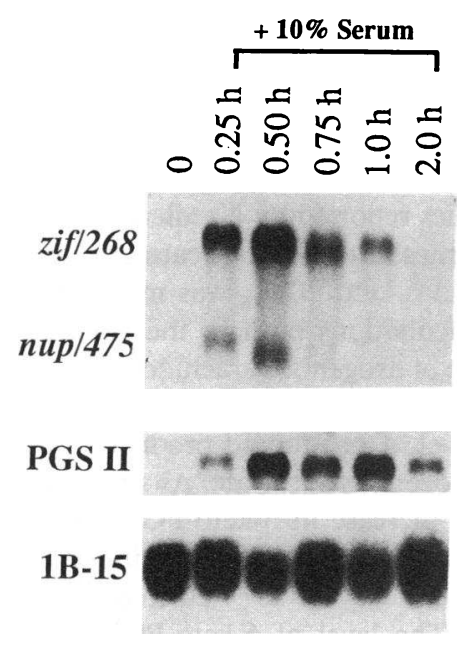
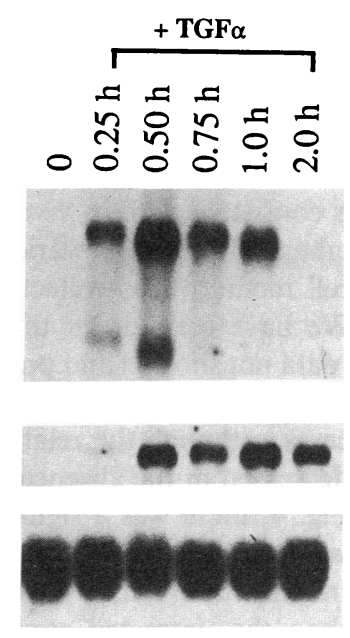

Figure 1. Induction of COX-2 mRNA, coordinate regulation with Nup/475 and Zif/268. Northern blotting was carried out to analyze mRNA isolated from RIE- 1 cells at the indicated times after TGF $\alpha$ or serum treatment. $3 \mu \mathrm{g}$ of mRNA was loaded from each time point. The cDNA probes used are denoted on the left side of the figure. PGS II represents a 4.5-kb mRNA, which hybridizes to the mouse COX-2 cDNA probe (see Methods). A cyclophilin 1B-15 probe was used to control for RNA loading. The autoradiographs were analyzed by scanning densitometry, and quantified, and levels are expressed in Results as fold increase after normalization to cyclophilin 1B-15 levels.

is a marked increase in a protein $\left[M_{\mathrm{r}} \sim 69,000\right]$ that immunoreacts with the COX-2 antibody (Fig. 2). When similar immunoblots were probed with a monospecific COX-1 antibody, no immunostaining was detected (data not shown). This experiment confirms the selective mitogen-dependent induction of the COX-2 enzyme in the RIE-1 cells.

$T G F \alpha$ regulation of eicosanoid production. After treatment of RIE-1 cells with TGF $\alpha$ or TPA, prostacyclin ( $\left.\mathrm{PGI}_{2}\right)$, measured as its nonenzymatic hydrolysis product, 6-keto-prostaglandin $(\mathrm{PG}) \mathrm{F}_{1 \alpha}$ (6-keto-PGF $\mathrm{F}_{1 \alpha}$ ), was the predominant prostanoid present (Fig. 3). We observed a fourfold stimulation of 6-keto-PGF ${ }_{1 \alpha}$ within $4 \mathrm{~h}$ after growth factor treatment and a 16-fold stimulation by TPA treatment during that same time period. In addition, $\mathrm{PGD}_{2}, \mathrm{PGE}_{2}, \mathrm{TxB}_{2}$, and $\mathrm{PGF}_{2 \alpha}$ production was increased following growth factor or phorbol ester

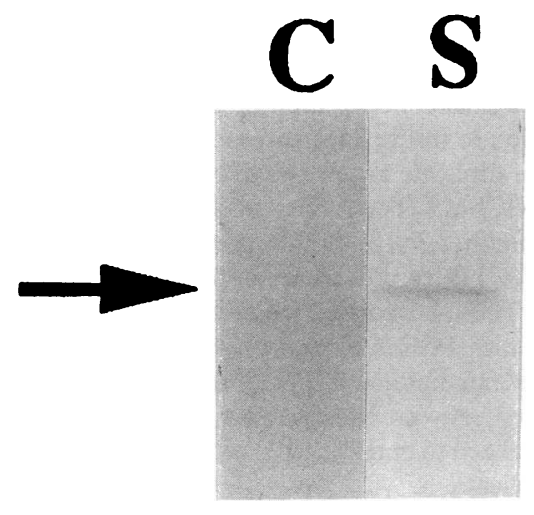

Figure 2. Induction of COX-2 protein. Microsomes were isolated from quiescent $(C)$ and 6-h TGF $\alpha$-stimulated (S) RIE-1 cells. $40 \mu \mathrm{g}$ of microsomal protein from the cells was electrophoresed in each lane and the proteins were electrophoretically transferred to nitrocellulose filters. Prestained molecular weight markers were run on the same gel and the immunoreactive band $\left(M_{\mathrm{r}} \sim 69,000\right)$ is shown by the arrow.

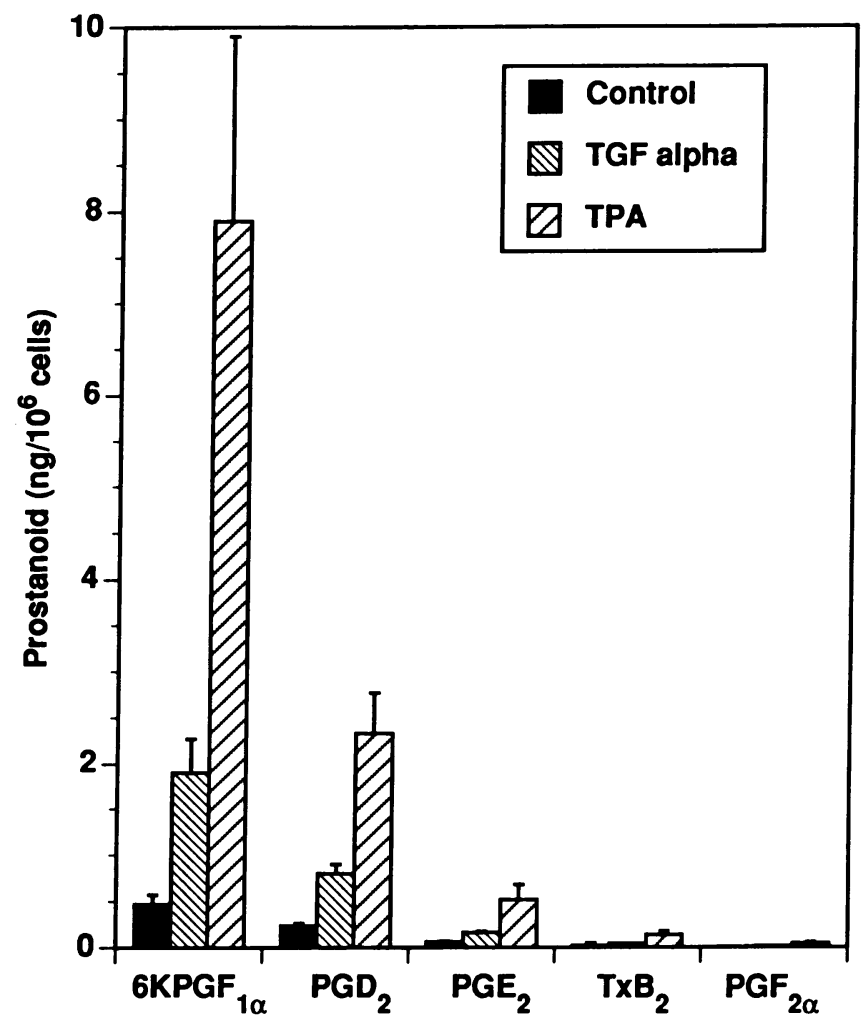

Figure 3. Eicosanoid production by RIE-1 cells. Quiescent RIE-1 cells were treated with TGF $\alpha(10 \mathrm{ng} / \mathrm{ml})$ or TPA $(100 \mathrm{ng} / \mathrm{ml})$ for $4 \mathrm{~h}$. Culture medium was removed from the cells and analyzed by $\mathrm{GC} /$ NICI-MS. Control (solid bar), TGF $\alpha$ (stippled bar), TPA ( hatched bar). This experiment was carried out in the absence (data not shown) and presence of $20 \mu \mathrm{M}$ arachidonic acid. The same fold increase was observed in both cases. The error bars in this and all subsequent figures represent the standard error.

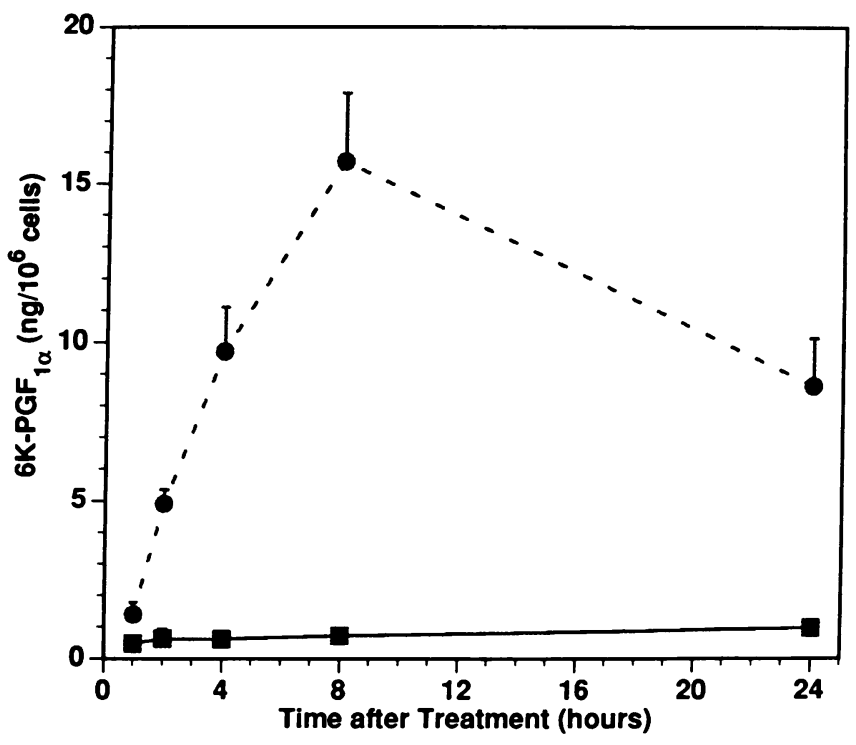

Figure 4. Time course for 6-keto-PGF $1 \alpha$ production. Quiescent RIE1 cells were treated with TGF $\alpha(10 \mathrm{ng} / \mathrm{ml}$; solid circles $)$ or serum-free medium ( solid squares). The experiments were carried out in triplicate at the indicated time points for each condition and 6-keto-PGF ${ }_{1 \alpha}$ levels in the culture media were normalized per $1 \times 10^{6}$ cells. Arachidonic acid was added to a final concentration of $20 \mu \mathrm{M}$ for the final $15 \mathrm{~min}$ of the incubation, to insure adequate substrate levels. 
A

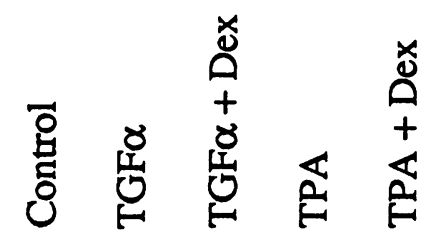

PGS
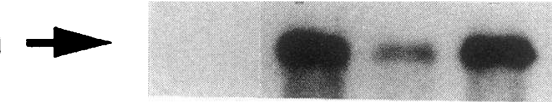

1B-15
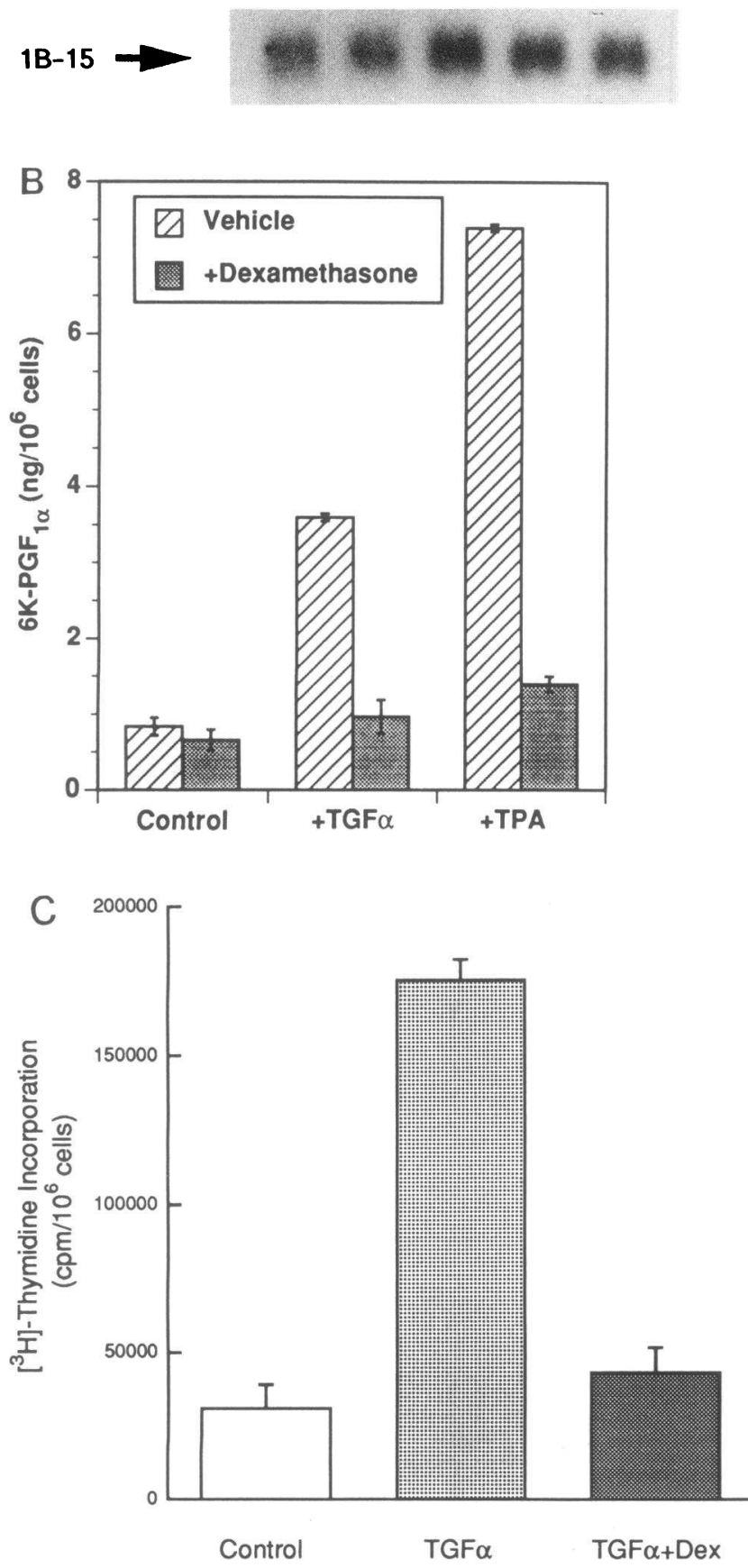

Figure 5. (A) Inhibition of COX-2 mRNA induction by pretreatment with dexamethasone. Quiescent RIE-1 cells were stimulated for 30 min with TGF $\alpha(10 \mathrm{ng} / \mathrm{ml})$ or TPA $(100 \mathrm{ng} / \mathrm{ml})$ in the presence or absence of $1 \mu \mathrm{M}$ dexamethasone. mRNA was then isolated from these cells and Northern blots were prepared ( $3 \mu \mathrm{g} /$ lane $)$ and hybridized to a ${ }^{32} \mathrm{P}$-labeled mouse COX-2 cDNA probe. The $4.5-\mathrm{kb}$ hybridizing treatment, albeit to a lesser extent than 6-keto-PGF ${ }_{1 \alpha}$. This experiment demonstrates that the RIE-1 cells are capable of growth-factor-regulated prostanoid synthesis, with 6-ketoPGF $_{1 \alpha}$ increased by fourfold $4 \mathrm{~h}$ after TGF $\alpha$ treatment and 16-fold $4 \mathrm{~h}$ after TPA treatment. Our finding that $\mathrm{PGI}_{2}$ is the predominant prostanoid produced by intestinal epithelial cells is consistent with in vivo studies reported by Needleman and others $(30,31)$. At various times after TGF $\alpha$ treatment, the cell medium was collected and 6-keto-PGF ${ }_{1 \alpha}$ was measured. We have carried out these incubations both in the absence (data not shown) and presence of exogenous arachidonic acid. We observed the same fold increase in PG synthesis in both cases, although the relative level of prostanoid produced was decreased in the absence of exogenous substrate. As shown in Fig. 4, there was a significant increase in 6-keto-PGF ${ }_{1 \alpha}$ level within $2 \mathrm{~h}$ after growth factor treatment. This continued to increase until $8 \mathrm{~h}$, at which time the level was $\sim 20$-fold higher than the untreated controls. The level of 6-keto-PGF ${ }_{1 \alpha}$ decreased significantly by the 24 -h time point. This experiment demonstrates that in addition to induction of COX-2 mRNA and protein, we also observed a marked time-dependent increase in the production of cyclooxygenase products as a result of growth factor treatment.

Inhibition of COX-2 mRNA induction, increase in cyclooxygenase activity, and mitogenesis by glucocorticoids. Other investigators (32) have shown that dexamethasone inhibits the induction of COX-2 mRNA. Therefore, we treated cells with dexamethasone before growth factor or TPA stimulation. The result of this experiment (Fig. $5 \mathrm{~A}$ ) demonstrates that the induction of the COX-2 mRNA is markedly inhibited by treating the cells with dexamethasone before adding the growth factor or tumor promoter. To determine if this inhibition was reflected by a decrease in cyclooxygenase activity after growth stimulation, we measured 6-keto-PGF ${ }_{1 \alpha}$ production in the presence and absence of dexamethasone. The results, demonstrated in Fig. $5 B$, indicate that dexamethasone pretreatment completely inhibited the increase in 6-keto-PGF $\mathrm{F}_{1 \alpha}$ formation after TGF $\alpha$ or TPA treatment. To determine if glucocorticoid treatment had any effect on TGF $\alpha$-stimulated mitogenesis, we treated the RIE- 1 cells with $1 \mu \mathrm{M}$ dexamethasone before addition of TGF $\alpha$ to the cell culture medium. The data shown in Fig. $5 C$ demonstrate that pretreatment of RIE-1 cells with dexamethasone markedly inhibits the incorporation of $\left[{ }^{3} \mathrm{H}\right]-$ thymidine into DNA at $18 \mathrm{~h}$ after growth factor treatment. These experiments indicate that glucocorticoids not only inhib-

band is shown at the arrow. This Northern blot was also hybridized to a ${ }^{32} \mathrm{P}$-labeled cyclophilin $1 \mathrm{~B}-15$ probe to demonstrate equivalent loading of RNA in each lane. $(B)$ Dexamethasone inhibition of 6keto-PGF $1 \alpha$ production in RIE-1 cells. Quiescent RIE-1 cells were pretreated for $4 \mathrm{~h}$ with $1 \mu \mathrm{M}$ dexamethasone and then treated with TGF $\alpha(10 \mathrm{ng} / \mathrm{ml})$ or TPA $(100 \mathrm{ng} / \mathrm{ml})$ for an additional $4 \mathrm{~h}$. Arachidonic acid was added to a final concentration of $20 \mu \mathrm{M}$ for the final $15 \mathrm{~min}$ of the incubation to insure adequate substrate levels. Medium was removed from triplicate samples and assayed for 6keto-PGF ${ }_{1 \alpha}$ levels by GC/NICI-MS. The results are shown in the absence of dexamethasone (hatched bars) and in the presence of dexamethasone (stippled bars). (C) Dexamethasone suppression of $\left[{ }^{3} \mathrm{H}\right]-$ thymidine incorporation in TGF $\alpha$-stimulated RIE-1 cells. Quiescent RIE- 1 cells were stimulated with TGF $\alpha(10 \mathrm{ng} / \mathrm{ml})$ plus and minus pretreatment with $1 \mu \mathrm{M}$ dexamethasone. $\left[{ }^{3} \mathrm{H}\right]$ Thymidine incorporation into DNA was measured between $18-20 \mathrm{~h}$ after growth factor treatment and results normalized to $\mathrm{cpm} / 1 \times 10^{6}$ cells. Each experiment was performed in triplicate. 
ited the increase in COX-2 mRNA and prostanoid production but also dramatically inhibited mitogenesis after TGF $\alpha$ treatment.

Inhibition of cyclooxygenase activity and TGF $\alpha$-stimulated mitogenesis by sulindac sulfide and indomethacin. We treated the RIE-1 cells with various concentrations of two known cyclooxygenase inhibitors (sulindac sulfide and indomethacin) before addition of growth factor to the cell culture medium. As shown in Fig. $6 \mathrm{~A}$, the addition of cyclooxygenase inhibitors markedly decreases prostanoid production. To determine if the inhibition of cyclooxygenase activity had an effect on mitogenesis, we measured $\left[{ }^{3} \mathrm{H}\right]$ thymidine incorporation into DNA after TGF $\alpha$ treatment in the presence of cyclooxygenase inhibitor. The data shown in Fig. $6 \mathrm{~B}$ demonstrate that addition of cyclooxygenase inhibitors markedly inhibits the incorporation of $\left[{ }^{3} \mathrm{H}\right]$ thymidine into DNA at $18 \mathrm{~h}$ after growth factor treatment. We found that sulindac sulfide was slightly more effective than indomethacin in inhibiting mitogenesis. These experiments indicate that, in addition to inhibiting prostanoid production, sulindac sulfide and indomethacin inhibit mitogenesis in the RIE-1 cells.

\section{Discussion}

In this report we demonstrate that a mitogen-inducible cyclooxygenase mRNA is elevated within $30 \mathrm{~min}$ and the level reaches 21 -fold above controls within $1 \mathrm{~h}$ after growth stimulation of RIE- 1 cells in culture. We have chosen to study the effects of TGF $\alpha$ on this pathway, since it is a potent epithelial mitogen and has been shown to be associated with progression of transformation in human colon cancer cells. We observed a fourfold increase in 6-keto-PGF $\mathrm{P}_{1 \alpha}$ production within $4 \mathrm{~h}$ and a 16-fold increase $8 \mathrm{~h}$ after TGF $\alpha$ treatment. TPA alone caused $\sim 10$-fold increase in 6-keto-PGF - $_{1 \alpha}$ production at $4 \mathrm{~h}$ after treatment. Since TPA was four times more effective than TGF $\alpha$ in stimulating eicosanoid production, it seems likely that signaling through a protein kinase $\mathrm{C}$ pathway is involved in the activation of eicosanoid production in RIE-1 cells, and that signaling through this pathway can achieve a greater stimulation of eicosanoid production at the 4-h time point. In addition, treatment of these cells with TGF $\alpha$ results in a dramatic increase in the level of a protein $\left(M_{\mathrm{r}} \sim 69,000\right)$, which immunoreacts with a monospecific COX-2 antibody on Western blots.

Sulindac is a pro-drug, which is converted in the liver and colon to the sulfide by reversible reduction (33). Sulindac sulfide and indomethacin appear indistinguishable in their ability to inhibit COX-1. Pretreatment of stimulated RIE-1 cells with sulindac sulfide or dexamethasone not only inhibits the induction of 6-keto-PGF ${ }_{1 \alpha}$ production, but also inhibits the mitogenic response of these cells to TGF $\alpha$. From these results, it seems plausible to consider the possibility that the mitogen-inducible cyclooxygenase may produce certain eicosanoids that play a role in growth regulation of intestinal epithelial cells. Inhibition of cyclooxygenase enzyme activity or prevention of its induction can modulate the proliferation of these cells. Obviously, the dexamethasone effect will require more experimentation to understand completely because it has been shown to prevent the induction of other immediate early genes in fibroblasts (34). It is of interest to note that the morphology of neu-, ras-, src-, and sis-transformed mouse fibroblasts became more normal after glucocorticoid treatment (35). Clearly, further investigation will be required to determine the precise role (if any) of COX-2 in the regulation of intestinal epithelial growth.
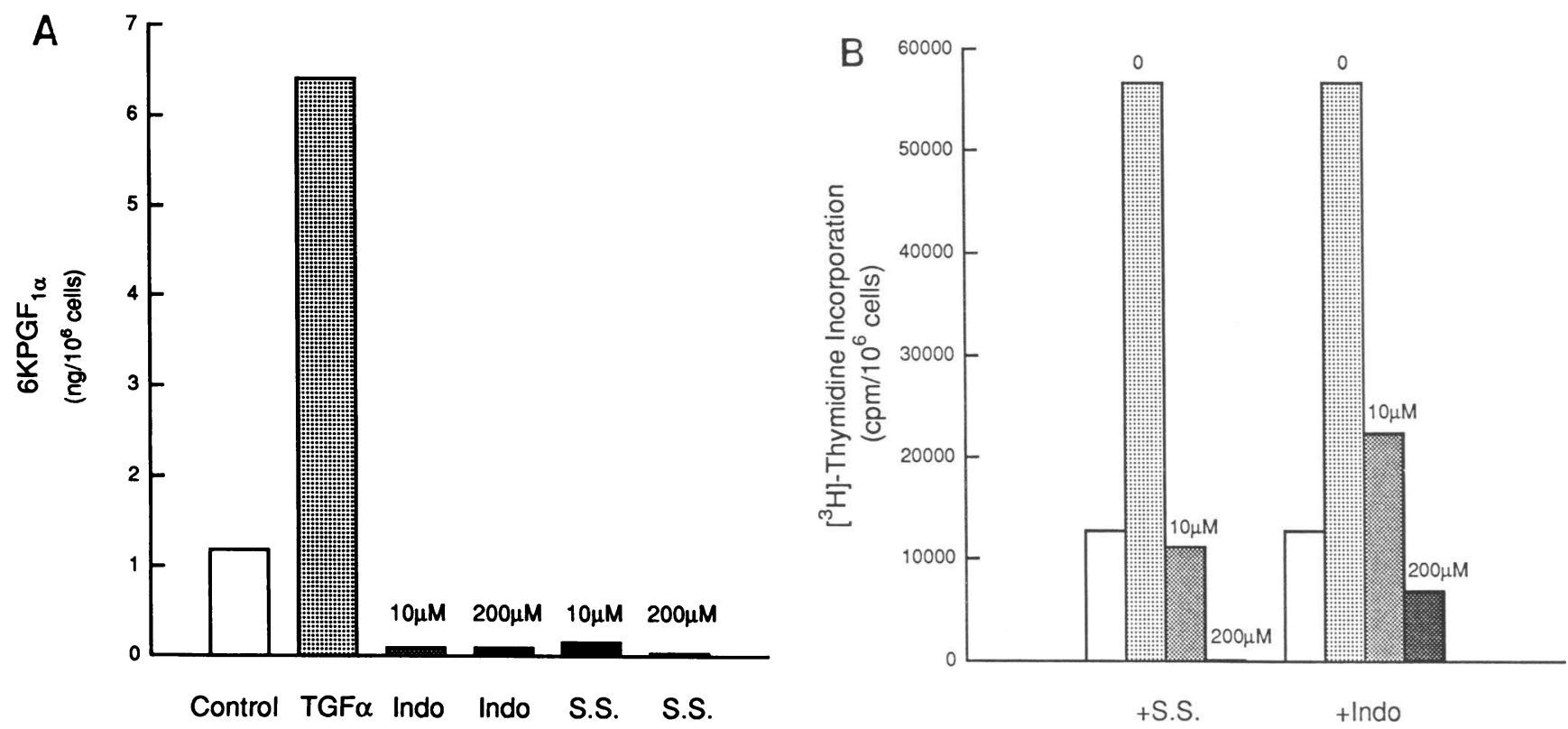

Figure 6. (A) Sulindac sulfide and indomethacin inhibition of 6-keto-PGF1 $\alpha$ synthesis. Quiescent RIE-1 cells were stimulated with TGF $\alpha$ (10 $\mathrm{ng} / \mathrm{ml}$ ) plus and minus sulindac sulfide (S.S.) or indomethacin (Indo) at the concentrations indicated. Arachidonic acid was added to a final concentration of $20 \mu \mathrm{M}$ for the final $15 \mathrm{~min}$ of the incubation, to insure adequate substrate levels. Medium was removed from triplicate samples and assayed for 6-keto-PGF ${ }_{1 \alpha}$ levels by GC/NICl-MS. The concentrations of sulindac sulfide and indomethacin used in these experiments did not affect RIE-1 cell viability (data not shown). (B) Inhibition of $\left[{ }^{3} \mathrm{H}\right]$ thymidine incorporation into DNA in TGF $\alpha$-stimulated RIE-1 cells by cyclooxygenase inhibitors. $\left[{ }^{3} \mathrm{H}\right]$ Thymidine incorporation into DNA was measured between $18-20 \mathrm{~h}$ after growth factor treatment and results normalized to $\mathrm{cpm} / 1 \times 10^{6}$ cells. Cells were treated at time 0 with TGF $\alpha(10 \mathrm{ng} / \mathrm{ml})$ and sulindac sulfide $(S . S$. ) or indomethacin (Indo) at the concentrations indicated above each bar. The open bar indicates the level of $\left[{ }^{3} \mathrm{H}\right]$ thymidine incorporation in the control (untreated) cells and is shown here for comparison. 
The COX-2 gene isolated from murine cDNA libraries (812 ) encodes a protein that shares only $\sim 42 \%$ amino acid sequence identity with COX-1 at the amino terminal region ( 102 amino acids from the start methionine); whereas, the amino acid identity over the rest of the protein is $\sim 66 \%$. The COX-2 enzyme has been shown to have an altered sensitivity to cyclooxygenase inhibitors (36). If the mitogen-inducible COX-2 enzyme is proven to play a role in growth regulation, then the availability of selective inhibitors will be important for clinical applications. If drugs are identified that inhibit the COX-2 enzyme preferentially, they may be efficacious in human colon cancer chemoprevention trials (5).

Work is currently underway to clone and characterize the rat and human intestinal mitogen-stimulated cyclooxygenase genes and evaluate the activity of the enzymes they encode with respect to substrate specificity and susceptibility to inhibition by known cyclooxygenase inhibitors. One group has recently cloned the genomic $5^{\prime}$ flanking sequence of the rat COX-2 gene, but to date the cDNA and/or coding sequence for this gene has not been reported (37).

Note added in proof: Since submission of this manuscript the rat COX2 cDNA sequence was published (Yamagata et al. 1993. Neuron. 11:371-386).

\section{Acknowledgments}

We thank J. Capdevila, R. Burk, L. Marnett, and M. R. Waterman for helpful suggestions; R. J. Coffey, for providing us with recombinant TGF $\alpha$; and T. Minton for technical assistance.

This work was supported in part by funds from the A. B. Hancock, Jr. Memorial Laboratory (R. N. DuBois), Lucille P. Markey Charitable Trust (R. N. DuBois), and the US Public Health Service under National Institutes of Health grants NIHES-00267 (R. N. DuBois), DK-26657-13 (R. N. DuBois), T-32 DK-07673-01A1 (P. R. Bishop), and GM-15431 (L. J. Roberts II). R. N. DuBois is the recipient of a Veterans Affairs Research Associate career development award, and a Boehringer Ingelheim New Investigator Award, and is an AGA Industry Research Scholar.

\section{References}

1. Thun, M. J., M. M. Namboodiri, and C. W. Heath, Jr. 1991. Aspirin use and reduced risk of fatal colon cancer. N. Engl. J. Med. 325:1593-1596.

2. Marnett, L. J. 1992. Aspirin and the potential role of prostaglandins in colon cancer. Cancer Res. 52:5575-5589.

3. Pollard, M., and P. H. Luckert. 1984. Effect of piroxicam on primary intestinal tumors induced in rats by N-methylnitrosourea. Cancer Lett. 25:117121.

4. Rosenberg, L., J. R. Palmer, A. G. Zauber, M. E. Warshauer, P. D. Stolley, and S. Shapiro. 1991. A hypothesis: nonsteroidal anti-inflammatory drugs reduce the incidence of large-bowel cancer. J. Nat. Cancer Inst. (Bethesda). 83:355-358.

5. Giardiello, F. G., S. R. Hamilton, A. J. Krush, S. Piantadosi, L. M. Hylind, P. Celano, S. V. Booker, C. R. Robinson, and G. A. Offerhaus. 1993. Treatment of colonic and rectal adenomas with sulindac in familial adenomatous polyposis. N. Engl. J. Med. 328:1313-1316.

6. Waddell, W. R., G. F. Gasner, E. J. Cerise, and R. W. Loughry. 1989. Sulindac for polyposis of the colon. Am. J. Surg. 157:175-178.

7. Boland, C. R. S. H. Itzkowitz, and Y. S. Kim. 1989. Colonic polyps and the gastrointestinal polyposis syndromes. In Gastrointestinal Disease: Pathophysiology, Diagnosis and Management. 4th ed. M. H. Sleisenger and J. S. Fordtran, editors. W. B. Saunders Co., Philadelphia. 1483-1518.

8. Kujubu, D. A., B. S. Fletcher, B. C. Varnum, R. W. Lim, and H. R. Herschman. 1991. TIS10, a phorbol ester tumor promoter-inducible mRNA from Swiss 3T3 cells, encodes a novel prostaglandin synthase/cyclooxygenase homologue. J. Biol. Chem. 266:12866-12872.

9. Xie, W. L., J. G. Chipman, D. L. Robertson, R. L. Erikson, and D. L. Simmons. 1991. Expression of a mitogen-responsive gene encoding prostaglandin synthase is regulated by mRNA splicing. Proc. Natl. Acad. Sci. USA. 88:2692-2696.

10. Hla, T., and K. Neilson. 1992. Human cyclooxygenase-2 cDNA. Proc. Natl. Acad. Sci. USA. 89:7384-7388.

11. O'Banion, M. K., V. D. Winn, and D. A. Young. 1992. cDNA cloning and functional activity of a glucocorticoid-regulated inflammatory cyclooxygenase. Proc. Natl. Acad. Sci. USA. 89:4888-4892.

12. Ryseck, R-P., C. Raynoschek, H. Macdonald-Bravo, K. Dorfman, M. G. Mattei, and R. Bravo. 1992. Identification of an immediate early gene, pghs-B, whose protein product has prostaglandin synthase/cyclooxygenase activity. Cell Growth \& Differ. 3:443-450.

13. Lau, L. F., and D. Nathans. 1991. Genes induced by serum growth factors. In Molecular Aspects of Cellular Regulation. Vol. 6. P. Cohen and J. G. Foulkes, editors. Elsevier, Amsterdam. 174-192.

14. Bravo, R. 1990. Genes induced during the $G_{0} / G_{1}$ transition in mouse fibroblasts. Semin. Cancer. Biol. 1:37-46.

15. Rollins, B. J., and C. D. Stiles. 1989. Serum inducible genes. $A d v$. Can. Res. 53:1-32.

16. Herschman, H. R. 1991. Primary response genes induced by growth factors and tumor promoters. Annu. Rev. Biochem. 60:281-319.

17. Kovary, K., and R. Bravo. 1991. The jun and fos protein families are both required for cell cycle progression in fibroblasts. Mol. Cell Biol. 11:4466-4472.

18. Holt, J. T., T. V. Gopal, A. D. Moulton, and A. W. Nienhuis. 1986 Inducible production of $c$-fos antisense RNA inhibits 3T 3 cell proliferation. Proc. Natl. Acad. Sci. USA. 83:4794-4798.

19. Nishikura, K., and J. M. Murray. 1987. Antisense RNA of proto-oncogene $c$-fos blocks renewed growth of quiescent 3T3 cells. Mol. Cell Biol. 7:639649.

20. Ziober, B. L., J. K. Willson, L. E. Hymphrey, K. Childress-Fields, and M. G. Brattain. 1993. Autocrine transforming growth factor-alpha is associated with progression of transformed properties in human colon cancer cells. J. Biol. Chem. 268:691-698.

21. Blay, J., and K. D. Brown. 1985. Functional receptors for epidermal growth factor in an epithelial-cell line derived from the rat small intestine. Biochem. J. 225:85-94.

22. DuBois, R. N., R. Graves-Deal, and R. J. Coffey. 1992. The mitogenic and genomic response of rat intestinal epithelial cells to TGF $\alpha$. Gastroenterology. 102:A803. (Abstr.)

23. Holtzman, M. J., J. Turk, and L. P. Shornick. 1992. Identification of a pharmacologically distinct prostaglandin $\mathrm{H}$ synthase in cultured epithelial cells. J. Biol. Chem. 267:21438-21445.

24. Schwab M., K. Alitalo, H. E. Varmus, and J. M. Bishop. 1983. A cellular oncogene (c-Ki-ras) is amplified, overexpressed, and located within karyotypic abnormalities in mouse adrenocortical tumor cells. Nature (Lond.). 303:497501 .

25. DuBois, R. N., M. W. McLane, K. Ryder, L. F. Lau, and D. Nathans 1990. A growth factor-inducible nuclear protein with a novel cysteine/histidine repetitive sequence. J. Biol. Chem. 265:19185-19191.

26. Clark, B. J., and M. R. Waterman. 1991. The hydrophobic amino-terminal sequence of bovine 17 alpha-hydroxylase is required for the expression of a functional hemoprotein in COS 1 cells. J. Biol. Chem. 266:5898-904.

27. Burnette, W. N. 1981. "Western blotting": electrophoretic transfer of proteins from sodium dodecyl sulfate-polyacrylamide gels to unmodified nitrocellulose and radiographic detection with antibody and radioiodinated protein $\mathrm{A}$ Anal. Biochem. 112:195-203.

28. Laemmli, U. K. 1970. Cleavage of structural proteins during the assembly of the head of bacteriophage T4. Nature (Lond.). 227:680-685.

29. Dworski, R., J. R. Sheller, N. E. Wicersham, J. A. Oates, K. L. Brigham, L. J. Roberts, and G. A. Fitzgerald. 1989. Allergen-stimulated release of mediators into sheep bronchoalveolar lavage fluid: effect of cyclooxygenase inhibition. Am. Rev. Resp. Dis. 139:46-51.

30. LeDuc, L. E., and P. Needleman. 1979. Regional localization of prostacyclin and thromboxane synthesis in dog stomach and intestinal tract. J. Pharmacol. Exp. Ther. 211:181-188.

31. Lee, D. Y., J. R. Lupton, and R. S. Chapkin. 1992. Prostaglandin profile and synthetic capacity of the colon: comparison of tissue sources and subcellular fractions. Prostaglandins. 43:143-164.

32. Kujubu, D. A., and H. R. Herschman. 1992. Dexamethasone inhibits mitogen induction of the TIS10 prostaglandin synthase/cyclooxygenase gene. $J$. Biol. Chem. 267:7991-7994.

33. Shen, T. Y., and C. A. Winter. 1978. Chemical and biological studies on indomethacin, sulindac and their analogs. In Advances in Drug Research A. B. Simmonds, editor. Academic Press, New York. 90-245.

34. Kawahara, R. S., Z. W. Deng, and T. F. Deuel. 1991. Glucocorticoids inhibit the transcriptional induction of JE, a platelet-derived growth factor-inducible gene. J. Biol. Chem. 266:13261-13266.

35. Matin, A., K. L. Cheng, T. C. Suen, and M. C. Hung. 1990. Effect of glucocorticoids on oncogene transformed NIH3T3 cells. Oncogene. 5:111-116.

36. Meade, E. A., W. L. Smith, and D. L. DeWitt. 1993. Differential inhibition of prostaglandin endoperoxide synthase (cyclooxygenase) isozymes by aspirin and other non-steroidal anti-inflammatory drugs. J. Biol. Chem. 268:6610-6614.

37. Sirois, J., L. O. Levy, D. L. Simmons, and J. S. Richards. 1993. Characterization and hormonal regulation of the promoter of the rat prostaglandin endoperoxide synthase 2 gene in granulosa cells. Identification of functional and protein-binding regions. J. Biol. Chem. 268:12199-12206. 